\title{
Alkaline phosphatase activity in relation to nutrient status in the northern Adriatic Sea
}

\author{
Ingrid Ivančić ${ }^{1, *}$, Tomislav Radić ${ }^{2}$, Daniel M. Lyons ${ }^{1}$, Dragica Fuks ${ }^{1}$, \\ Robert Precali ${ }^{1}$, Romina Kraus ${ }^{1}$
}

${ }^{1}$ Center for Marine Research, Ruđer Bošković Institute, G. Paliaga 5, 52210 Rovinj, Croatia

${ }^{2}$ Institute for Adriatic Crops and Karst Reclamation, Put Duilova 11, 21000 Split, Croatia

\begin{abstract}
During 2004 and 2006, alkaline phosphatase activity (APA) was measured in the northern Adriatic to establish whether it is an important mechanism for phosphorus recycling in this area, which is poor in orthophosphate $\left(\mathrm{PO}_{4}\right)$. From May to September, in conditions of exhausted $\mathrm{PO}_{4}$, microbes in upper waters induced high APA (0.41 to $\left.5.55 \mu \mathrm{mol}^{-1} \mathrm{~h}^{-1}\right)$ to obtain phosphorus from the dissolved organic pool. The highest APA was found during spring and summer freshets due to the strongly deficient $\mathrm{PO}_{4}$ versus inorganic nitrogen supply from the Po River. During the summer months, APA was lower yet still important for phosphorus recycling. In these months, the low Po River nitrogen supply resulted in lower microbial biomass and, consequently, lower APA. From October to December, APA in upper waters was low $\left(<0.2 \mu \mathrm{mol}^{-1} \mathrm{~h}^{-1}\right)$, even during large microbial blooms. During autumn blooms, $\mathrm{PO}_{4}$ was probably supplied from deeper waters. In deeper waters, with an almost balanced inorganic N:P ratio for microbial requirements, APA was generally irrelevant during the entire investigation period. Our results emphasise the role of APA in meeting the seasonal microbial phosphorus requirements in the northern Adriatic.
\end{abstract}

KEY WORDS: APA $\cdot$ DOP $\cdot$ Nutrients $\cdot$ Phytoplankton $\cdot$ Bacteria $\cdot$ Northern Adriatic

Resale or republication not permitted without written consent of the publisher

\section{INTRODUCTION}

The northern Adriatic Sea is modelled by the alternating influence of freshwater, mainly from the Po River, and middle Adriatic waters. These 2 water bodies, characterised by different thermohaline properties and different nutrient content, influence the circulation and biological cycle in the region. During winter the prevailing cyclonic circulation ('open' type) brings warmer, more saline oligotrophic middle Adriatic waters into the region. In late spring, formation of gyres cause lower exchange with the middle Adriatic ('closed' type) and this situation usually persists during summer (Franco \& Michelato 1992, Artegiani et al. 1997, Lyons et al. 2007).

In Po River waters, the average total phosphorus (P) and total nitrogen $(\mathrm{N})$ concentrations in the 1999 to 2002 period (5.16 and $285.71 \mu^{m o l ~ ~^{-1}}$, respectively;
Milan et al. 2003) were more than an order of magnitude higher than in northern Adriatic waters (Giani 2003). In river waters, the concentration of dissolved inorganic $\mathrm{N}$ (DIN) is markedly higher than that of $\mathrm{PO}_{4}$, resulting in a high inorganic N:P ratio (about 100; Milan et al. 2003). During the period with 'closed' circulation, Po River runoff greatly influences nutrient content in the northern Adriatic, causing a trophic gradient in this area. High microbial activity and eutrophication are characteristic for the western area, while the eastern area is more oligotrophic with lower microbial activity (Gilmartin \& Revelante 1983, Gilmartin et al. 1990, Karner et al. 1992). Furthermore, Po River waters influence the $\mathrm{N}: \mathrm{P}$ of the region. An inorganic $\mathrm{N}: \mathrm{P}$ ratio of about 60 was estimated for productive lower-salinity northern Adriatic waters during the 1970s (Degobbis 1990), and has further increased since the mid-1980s (Degobbis et al. 2000). The strongly 
unbalanced N:P ratio for microbial requirements (balanced N:P = 16:1 for phytoplankton, Redfield et al. 1963; 9:1 for bacteria, Goldman et al. 1987) and the low concentrations of $\mathrm{PO}_{4}$ (Ivančić \& Degobbis 1987) led to the presumption that $\mathrm{P}$ is the limiting element for microbial growth. Bioassays based on selective nutrient additions to natural plankton communities have also identified P-limitation (Pojed \& Kveder 1977, Chiaudani \& Vighi 1982, Filipić et al. 1989).

Organic P concentrations generally exceed $\mathrm{PO}_{4}$ concentrations (Ivančić \& Degobbis 1987, Lipizer et al. 1999, Cozzi et al. 2002) and may be an important source of $\mathrm{P}$ for microbial communities. In the presence of low $\mathrm{PO}_{4}$ concentrations, both phytoplankton and bacteria can induce extracellular alkaline phosphatase which enables them to use organic P esters as a source of P. Alkaline phosphatase activity (APA) has been used for many aquatic systems as an indicator of $\mathrm{P}$ deficiency (Hoppe 2003).

Data for APA in combination with inorganic nutrients, dissolved organic P (DOP) and parameters characterising microbial biomass can provide useful information on the availability of $\mathrm{P}$ in an ecosystem. In order to establish the role of APA in describing DOP as a potential phosphorus source for microbes in various ambient conditions in the northern Adriatic, APA was measured in different seasons during 2004 along a transect where conditions change from oligotrophic to eutrophic. Furthermore, in order to check the relative importance of APA in different pools, dissolved and particulate APA were determined in 2006 during microbial blooms induced by freshwater imported nutrients and in summer with minimal freshwater influence and low microbial biomass.

\section{MATERIALS AND METHODS}

Sampling strategy. Measurements were carried out at 6 stations along a transect from the Po River delta to Rovinj (Po transect) located in the northern Adriatic (Fig. 1) during 7 cruises performed from May to December 2004. Stations were located along the trophic gradient, following the decreasing influence of Po river waters. Conventional parameters (temperature, salinity, inorganic nutrients, DOP, chlorophyll a [chl a $]$, bacteria and microphytoplankton abundance) and total APA were measured at 5 depths (surface, 5, 10,20 , and $1 \mathrm{~m}$ from the bottom; bottom depth was between 28 to $36 \mathrm{~m}$ ). In 2006 APA in different fractions was determined during microbial blooms in the Po River plume in May, September and October, as well as in June during minimal freshwater input and low microbial biomass.

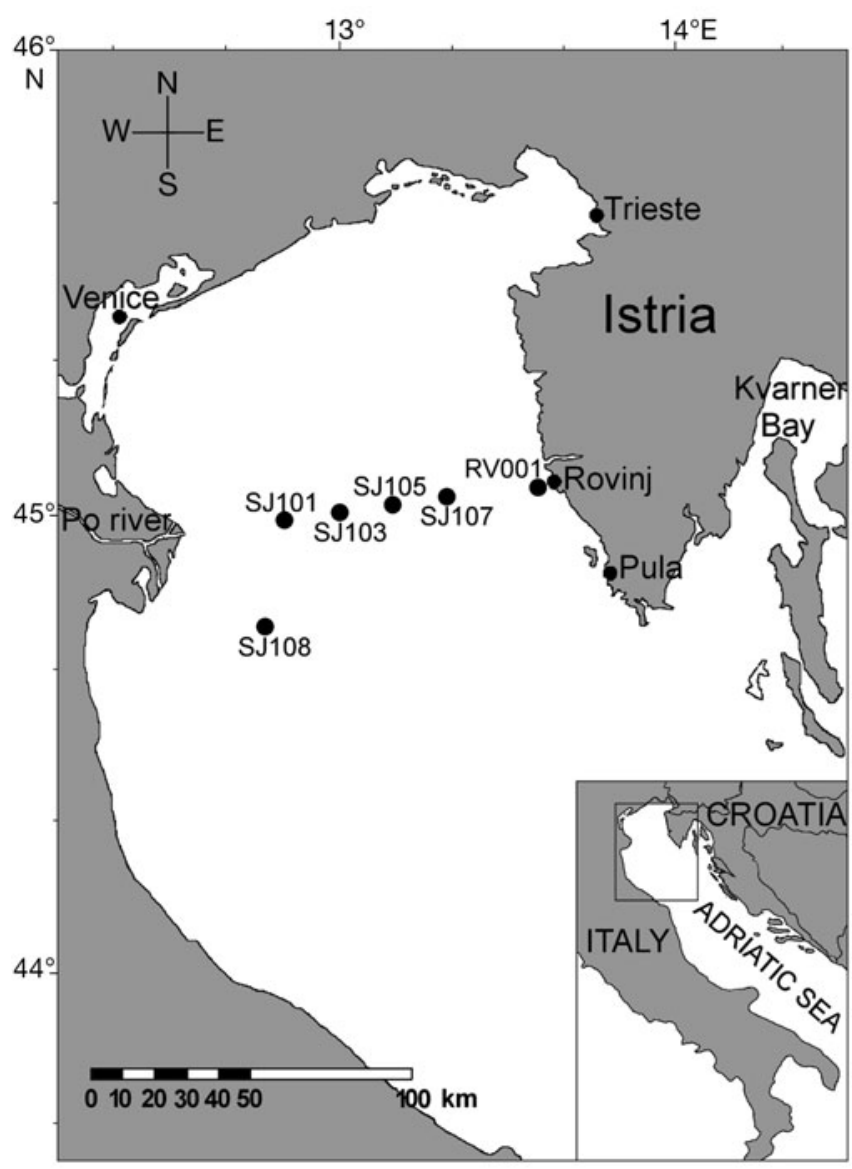

Fig. 1. Research area and sampling stations in the northern Adriatic Sea

Analytical protocol. Water samples were collected with 51 PVC Niskin samplers. Temperature and salinity profiles were acquired during the downcasts of a Seabird SBE 25 CTD probe.

Inorganic nutrients were analysed from unfiltered water immediately after collection (Strickland \& Parsons 1972, Ivančić \& Degobbis 1984). In a few cases, when the sample was turbid, measurements were corrected by a turbidity blank. Samples for total dissolved phosphorus were filtered (Whatman GF/C, precombusted at $500^{\circ} \mathrm{C}$ ) and stored in polyethylene tubes at $-30^{\circ} \mathrm{C}$. Analyses were performed using a chemical combustion method with persulphate (Menzel \& Corwin 1965). DOP was calculated by subtracting $\mathrm{PO}_{4}$ from total dissolved P. DIN was calculated as the sum of nitrate, nitrite and ammonia. N:P ratios were calculated as DIN: $\mathrm{PO}_{4}$, after assigning the value of the limit of detection $\left(0.03 \mu \mathrm{mol} \mathrm{l}^{-1}\right)$ to $\mathrm{PO}_{4}$ concentrations below the detection limit.

APA was determined in unfiltered seawater (total APA) and seawater filtered through a $0.22 \mu \mathrm{m}$ filter (dissolved APA). All APA measurements were performed in triplicate immediately after sample collec- 
tion. APA was measured with a fluorogenic substrate analogue (Hoppe 1983) using methylumbelliferyl phosphate at a final concentration of $50 \mu \mathrm{mol} \mathrm{l}^{-1}$. This concentration, also used by Danovaro et al. (2005) for APA determination in the northern Adriatic, was chosen since in a preliminary study (I. Ivančić \& T. Radić unpubl.), it was observed that in seawater with various microbial activities, saturation with substrate was always achieved. Furthermore, not only do higher substrate concentrations increase background fluorescence, but a decrease in activity was also observed at concentrations higher than $50 \mu \mathrm{mol} \mathrm{l^{-1 }}$ in that preliminary study; this has also been reported by Sebastian \& Niell (2004). Incubation was performed in the dark at the in situ temperature and $\mathrm{pH}$ to obtain maximum activity in ambient conditions. Fluorescence was measured immediately after substrate addition and after incubation for about $1 \mathrm{~h}$ using a Turner TD-700 fluorometer with excitation at $365 \mathrm{~nm}$ and emission at 460 $\mathrm{nm}$. APA was calculated as the difference of these 2 measurements divided by the incubation time after calibration of the fluorometer with methylumbelliferone. Results are presented as the mean value of triplicates. From October to December, in conditions of low APA, the differences between triplicates were not significant (coefficient of variation, $\mathrm{CV}<1 \%$ ). From May to September, when APA was high, $12 \%$ of samples showed significant variation $(\mathrm{CV}>5 \%)$.

Total chl a concentrations were determined by filtration on Whatman GF/C filters. For the determination of the nano fraction, a $20 \mu \mathrm{m}$ nylon net was used. Filters were frozen $\left(-30^{\circ} \mathrm{C}\right)$ and analysed within a few days following an acidification fluorometric procedure in $90 \%$ acetone (Strickland \& Parsons 1972).

Samples for microphytoplankton determination (200 ml) were filtered through a $300 \mu \mathrm{m}$ mesh plankton net, preserved with Lugol solution (2\% final concentration) and buffered with sodium acetate. Microphytoplankton abundance and composition were determined at 200× magnification using a Zeiss inverted microscope after $40 \mathrm{~h}$ sedimentation of a $50 \mathrm{ml}$ subsample using the Utermöhl (1958) settling technique.

Samples for bacterial abundance (BA) were preserved with formaldehyde ( $2 \%$ final concentration) and stored at $4^{\circ} \mathrm{C}$. BA was determined by cell-counting using an epifluorescence microscope after DAPI staining (Porter \& Feig 1980).

BA was converted to carbon (C) content by a conversion factor of $20 \mathrm{fg} \mathrm{C} \mathrm{cell}^{-1}$ (Lee \& Fuhrman 1987), while phytoplankton biomass was converted using a factor of $50 \mu \mathrm{g}$ C per $\mu \mathrm{g}$ chl a (Antia et al. 1963). Specific APA in upper waters ( 0 to $10 \mathrm{~m}$ ) was calculated by dividing total APA with $\mathrm{C}$ content in microorganisms. Total APA was used since, in 2004, particulate APA was not determined. In upper waters, APA was well correlated with microbial biomass during both years, and measurements carried out in 2006 showed that nearly all APA was in particulate form. In the layer from $20 \mathrm{~m}$ to the bottom, APA was not correlated with microbial biomass, and measurements carried out in 2006 showed that most of the activity was related to free enzymes, thus the specific activity in bottom waters could be overestimated and was not taken into account.

The relationships between APA and relevant parameters were tested using Spearman's rank correlation for data not having a Gaussian distribution. The relative importance of parameters on APA was tested by multiple regression analyses on log-transformed data ( $\log$ (value +1$)$ to avoid problems with 0 values), as multiple regression is not suitable for data not having a Gaussian distribution.

\section{RESULTS}

\section{Environmental conditions and APA evolution}

\section{Hydrographical conditions}

In May 2004, a large impulse of Po River discharge (up to $5400 \mathrm{~m}^{3} \mathrm{~s}^{-1}$, Fig. 2a) influenced the salinity of upper waters over the entire investigated area (35.5 to 36.6; Fig. 2b). Minimal salinity was found in the area SE of the Po delta (Stn SJ108) and gradually increased eastwards. The water column was stratified with lower-salinity warmer water in the upper $10 \mathrm{~m}$, and colder higher-salinity water down to the bottom (Fig. 2b,c). During summer the Po River discharge had, as usual, smaller impulses (Fig. 2a). The Po regime in combination with 'closed' circulation observed during that summer (N. Supić pers. comm.) caused retention of lower-salinity water in the upper $10 \mathrm{~m}$ of the region, as illustrated for the beginning of September (Fig. 2d). Below $20 \mathrm{~m}$ depth, higher salinity and colder water was present (Fig. 2d,e). In October, Po River discharge was low (Fig. 2a), although, since the circulation was still 'closed' (N. Supić pers. comm.), lower-salinity water circulated in the upper $10 \mathrm{~m}$ of the region (Fig. 2f). Below $20 \mathrm{~m}$ a decrease in salinity (by up to 0.5 ) and increase of temperature (by up to $5^{\circ} \mathrm{C}$ ) occurred from September (Fig. 2g), indicating that mixing throughout the water column had already started. The high Po River discharge in November did not influence the basin since the river waters were directed southward in a narrow coastal belt due to the re-established 'open' circulation (N. Supić pers. comm.). In this month mixing processes were completed and temperature and salinity were homogeneous throughout the water column (Fig. 2h,i). A similar situation existed in December (data not shown). 

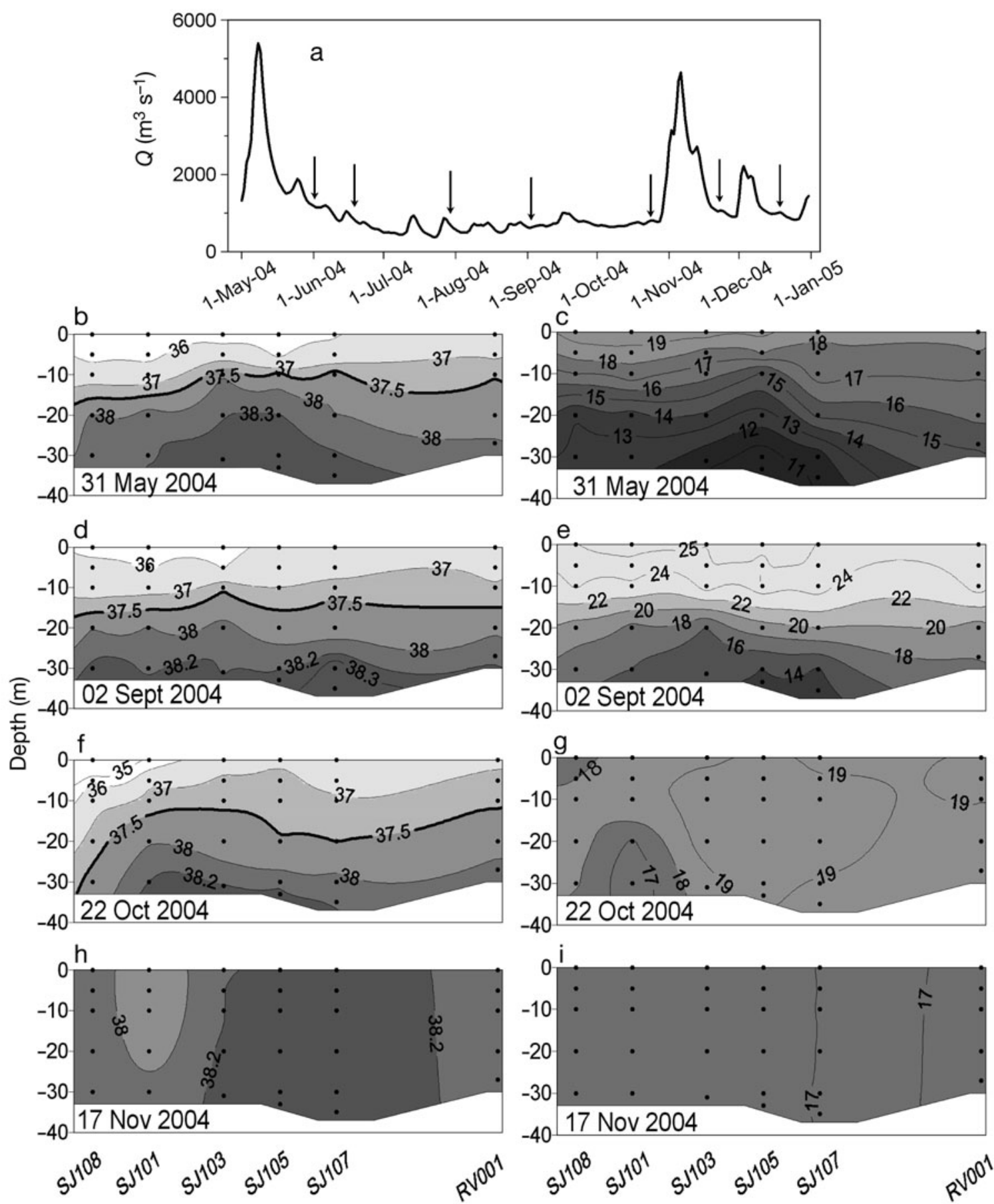

Fig. 2. (a) Daily mean of the Po River discharge rate during 2004 with cruise dates denoted by arrows. Salinity (b,d,f,h) and temperature (c,e,g,i) distributions in 2004 at sampling stations shown in Fig. 1

\section{Microbial biomass evolution}

At the surface, maximal phytoplankton biomass in the entire investigated area was observed in October (Fig. 3a). The highest chl a concentration was observed in the area SE of the Po River delta

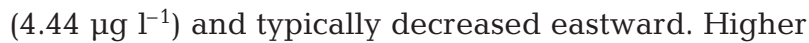

surface chl a was also found in May, September and November (up to $2.67 \mathrm{gg} \mathrm{l}^{-1}$ ). In June and July, surface values were minimal during the investigation period $\left(0.25\right.$ to $\left.1.29 \mu \mathrm{g} \mathrm{l}^{-1}\right)$. At 5 and $10 \mathrm{~m}$, seasonal changes and horizontal distribution were similar to that at the surface, but chl a diminished with depth (data not shown). In deeper waters, seasonal and hori- 
zontal changes of chl a were less pronounced than in the upper $10 \mathrm{~m}$. At $20 \mathrm{~m}$ depth, values did not change markedly with the season, nor along the transect, while in the bottom layer, values were maximal during summer (up to $1.44 \mu \mathrm{g} \mathrm{l}^{-1}$, data not shown). At the surface, maximal BA was found in May (up to $1780 \times$ $10^{6} \mathrm{l}^{-1}$ ) with further elevated values in September and October $\left(810 \times 10^{6}\right.$ to $\left.1360 \times 10^{6} \mathrm{l}^{-1}\right)$. The highest values were always found in the area SE of the Po River delta and decreased eastward (Fig. 3b). Minimal surface BA was found in June and December $\left(250 \times 10^{6}\right.$ to $650 \times 10^{6} \mathrm{l}^{-1}$ ). Seasonal and horizontal changes of BA were basically similar in the upper $10 \mathrm{~m}$ of the water column, but intensity of the changes decreased with depth (data not shown). Below this depth, BA did not differ markedly along the transect, and the seasonal changes were also less pronounced compared to the upper waters (data not shown). Generally it is possible to discern 2 periods: July to September (at the bottom, July to November) with higher values (>500 $\times$ $10^{6}$ to $1260 \times 10^{6} \mathrm{l}^{-1}$ ), and May to June and December with lower values $\left(120 \times 10^{6}\right.$ to $\left.500 \times 10^{6} \mathrm{l}^{-1}\right)$.

\section{Nutrient status and APA}

At the surface, $\mathrm{PO}_{4}$ concentrations were very low during the entire year $\left(<0.05 \mu \mathrm{mol} \mathrm{l}^{-1}\right)$, except for a higher value $\left(0.13 \mu \mathrm{mol} \mathrm{l}^{-1}\right)$ found in the area SE of the Po River delta in December (Fig. 4a). Surface DOP concentrations (Fig. 4b) were several times higher than those of $\mathrm{PO}_{4}$, accounting for $>90 \%$ of $\mathrm{P}$ in the total dissolved P pool. During May to September, DOP (0.01 to $0.18 \mu \mathrm{mol} \mathrm{l}^{-1}$ ) was markedly lower than in the October to December period (0.20 to $\left.0.56 \mu \mathrm{mol} \mathrm{\textrm {l } ^ { - 1 }}\right)$ during
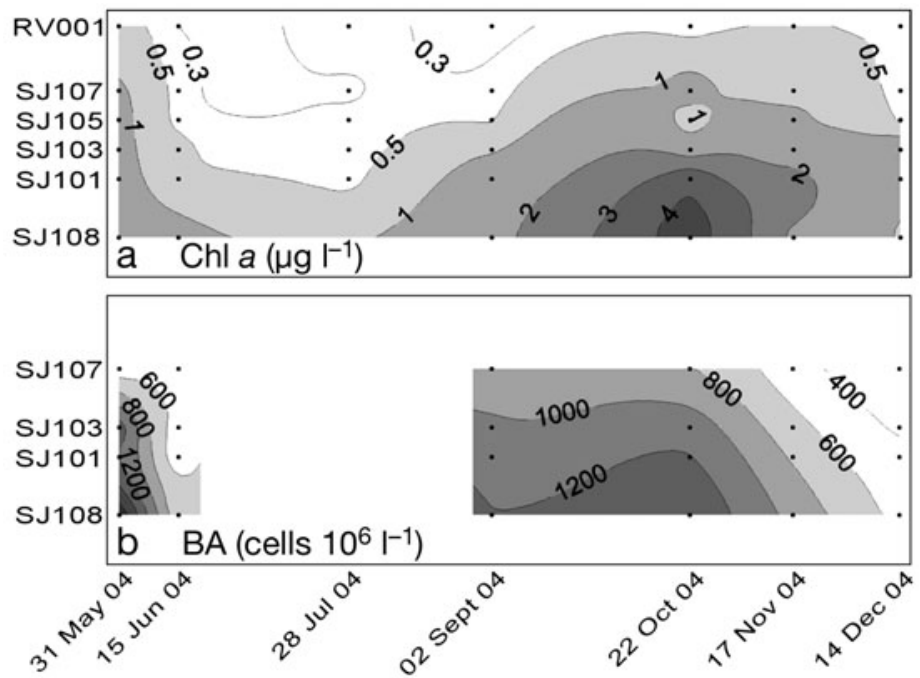

Fig. 3. (a) Chl $a$ and (b) bacterial abundance (BA) distributions at the surface in 2004 at sampling stations shown in Fig. 1 which DOP progressively increased. DIN (0.33 to 6.61 umol $\mathrm{l}^{-1}$; Fig. 4c) was present in marked surplus with respect to $\mathrm{PO}_{4}$ throughout the entire year, resulting in a high N:P ratio (generally 50 to 200 ; data not shown). DIN concentrations were usually maximal in the area SE of the Po delta and decreased eastward. During the freshet in May, DIN concentrations were high, decreased during summer (minimum in June), again increased in autumn and remained high in winter (Fig. 4c). Along with the high DIN concentrations in May, maximal APA was found (Fig. 4d) with a peak in the area SE of the Po River delta (up to $5.55 \mu \mathrm{mol}$ $\mathrm{l}^{-1} \mathrm{~h}^{-1}$ ). Activity slowly decreased eastward, being lowest in the eastern coastal area $\left(1.43 \mu \mathrm{mol} \mathrm{l}^{-1} \mathrm{~h}^{-1}\right)$. This spatial trend persisted during the stratification period. Although during summer, with low freshwater runoff and lower DIN concentrations, APA decreased (Fig. $4 \mathrm{~d})$ in the entire area, especially in June, yet was still considerable $\left(0.41\right.$ to $\left.3.05 \mu \mathrm{mol} \mathrm{l}^{-1} \mathrm{~h}^{-1}\right)$. From October a progressive reduction of APA occurred (Fig. 4d) and values (generally $<0.2 \mu \mathrm{mol} \mathrm{l}^{-1} \mathrm{~h}^{-1}$ ) were more than an order of magnitude lower than in previous months.

Since strong fluctuations in microbial biomass (Fig. 3a,b) were observed, specific APA (APA per C content in phytoplankton and bacteria) was calculated to eliminate the effect of difference in biomass. At the surface, specific APA was high in May, June and September (17.45 to $58.31 \mathrm{nmol} \mu \mathrm{gC}^{-1} \mathrm{~h}^{-1}$ ) and low from October to December (0.49 to $3.48 \mathrm{nmol}$ $\mu \mathrm{gC}^{-1} \mathrm{~h}^{-1}$; Fig. 4e). While APA markedly decreased from May to June (Fig. 4d), the respective decrease of specific APA was considerably less pronounced (Fig. 4e). Furthermore, unlike APA, the decrease of specific APA from west to east was noticeably less pronounced.

At depths of 5 and $10 \mathrm{~m}$, changes in APA (Fig. A1 in Appendix 1, available as supplementary material at: www.int-res.com/articles/ suppl/m378p027_app.pdf), specific APA (data not shown) and the nutrient pattern (data not shown) were generally the same as at the surface, although values of parameters showed a small decrease with depth, as shown for APA. From $20 \mathrm{~m}$ to the bottom, APA was generally $<0.2 \mu \mathrm{mol} \mathrm{l}^{-1} \mathrm{~h}^{-1}$, except for higher activity in May and June in the western and central areas (up to $0.96 \mu \mathrm{mol} \mathrm{l}^{-1} \mathrm{~h}^{-1}$; Supplementary Figs. A1 \& A2). In these waters no significant APA variation by area or season was found, independently of changes in $\mathrm{PO}_{4}$ and DIN concentrations and the general predomination of DOP (>80\%) in the total dissolved $\mathrm{P}$ pool. It is important to point out that in these deeper waters the disproportion between DIN and $\mathrm{PO}_{4}$ was less marked than in upper waters, and at the bottom N:P was often 

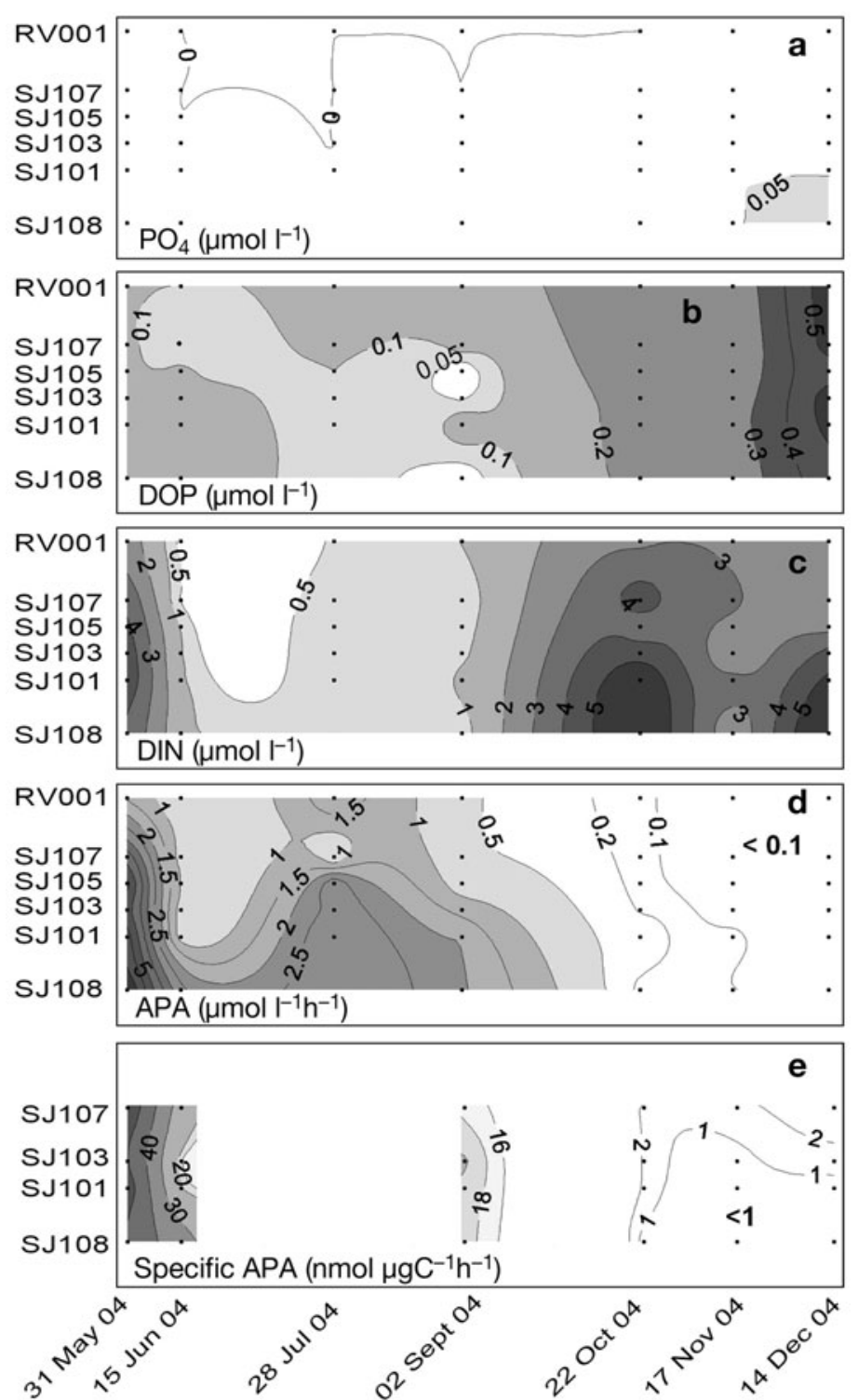

Fig. 4. (a) $\mathrm{PO}_{4}$, (b) dissolved organic phosphorus (DOP), (c) dissolved inorganic nitrogen (DIN), (d) alkaline phosphatase activity (APA) and (e) specific APA distributions at the surface in 2004 at sampling stations shown in Fig. 1. At Stns SJ105 and RV001, as well as during the cruise of 28 July 2004, specific APA could not be calculated since bacterial abundance was not determined

close to the optimum for microbial growth (generally $\mathrm{N}$ :P was 9 to 21; data not shown).

Results obtained at 2 stations in 2006 confirmed the same seasonal trends of APA, specific APA and other related parameters (Table A1 in supplementary material). Maximal activity was found during the freshets through the stratification period, while the starting of mixing processes in the water column drastically reduced activity. Measurements in different fractions showed that on all sampling dates, APA was mostly in the particulate fraction ( 71 to $100 \%$ ), particularly at the surface $(>96 \%)$, while activity of free enzymes was not significant (Table A1). On the contrary, at the bottom, the contribution of free enzymes (65 to $100 \%$ ) was the most important.

\section{Relationship of APA with relevant parameters}

During both investigated years, APA in upper waters was typically found to be high during May to September, characterised by stratification in the water column, and low during October to November, characterised by mixing in the water column. The correlations with relevant parameters were determined separately for these periods with contrasting APA. During the stratification period, correlations were performed separately for upper and deeper waters, while during the mixing period correlations were performed for the entire water column since values of all parameters were homogeneously distributed through the whole water body.

During the stratification period, APA in upper waters was significantly negatively correlated with salinity but not with temperature (Table 1). Furthermore, APA was significantly positively correlated with DIN but not with $\mathrm{PO}_{4}$, whose concentrations in these waters were always very low, and with DOP. The correlations of APA with chl $a$ and BA were also positively significant. DIN, chl $a$ and BA were also significantly negatively correlated with salinity, while chl $a$ and BA were in significant positive correlation with DIN and with each other (data not shown). Multiple regression analysis indicated that during this period in upper waters, $80 \%$ of the APA variability could be explained by nutrients and microbial biomass. The most significant contributions to APA variability were that of DIN (28\%), chl a $(16 \%)$ and BA $(26 \%)$ (Table 1$)$.

During the stratification period in deeper waters, where APA was low, significant negative correlations of APA with $\mathrm{PO}_{4}$, DIN as well as with chl $a$ and BA were found (Table 1). The correlations with temperature, salinity and DOP were not significant. $\mathrm{PO}_{4}$ and DIN were in significant positive correlation, as was chl $a$ with DIN and BA. Multiple regression analysis suggested that in these waters only $36 \%$ of APA variability could be explained by nutrients and microbial biomass. The most significant factors for APA variability were BA $(21 \%)$ and orthophosphate $(9 \%)$, while little variability could be explained by the other parameters (Table 1). 
Table 1. Correlations of alkaline phosphatase activity (APA) with relevant parameters during the stratification (May to September) and mixing (November and December) periods in 2004 and 2006. Results for October were not included since mixing processes in the water column had started but were not completed. ++ and -- correspond to $\mathrm{p}<0.001$ for positive and negative correlations, respectively; + and - correspond to $\mathrm{p}<0.05$. ns: not significant. \%: variability of APA explained by the respective parameter as estimated by multiple regression at $p<0.05$. DOP: dissolved organic phosphorus. DIN: dissolved inorganic nitrogen. BA: bacterial abundance

\begin{tabular}{|c|c|c|c|c|c|c|c|c|c|}
\hline \multirow{3}{*}{ Parameter } & \multicolumn{6}{|c|}{ Stratification -} & \multirow{2}{*}{\multicolumn{3}{|c|}{$\begin{array}{l}\text { Mixing } \\
\text { Water column }\end{array}$}} \\
\hline & \multicolumn{3}{|c|}{0 to $10 \mathrm{~m}$} & \multicolumn{3}{|c|}{$20 \mathrm{~m}$ to bottom } & & & \\
\hline & $\mathrm{p}$ & $\mathrm{n}$ & $\%$ & $\mathrm{p}$ & $\mathrm{n}$ & $\%$ & $\mathrm{p}$ & $\mathrm{n}$ & $\%$ \\
\hline Temp. $\left({ }^{\circ} \mathrm{C}\right)$ & ns & 75 & & ns & 57 & & ns & 64 & \\
\hline Salinity & -- & 75 & & ns & 57 & & ns & 64 & \\
\hline $\mathrm{PO}_{4}\left(\mu \mathrm{mol} \mathrm{l} l^{-1}\right)$ & ns & 75 & 8 & - & 57 & 9 & ns & 64 & 2 \\
\hline DOP $\left(\mu \mathrm{mol} \mathrm{l} \mathrm{l}^{-1}\right)$ & ns & 75 & 2 & ns & 57 & 1 & ns & 64 & 4 \\
\hline $\operatorname{DIN}\left(\mu \mathrm{mol} \mathrm{l}^{-1}\right)$ & ++ & 75 & 28 & - & 57 & 4 & ns & 64 & 2 \\
\hline Chl $a\left(\mu g l^{-1}\right)$ & ++ & 63 & 16 & - & 45 & 1 & ++ & 64 & 42 \\
\hline BA $\left(10^{6}\right.$ cells $\left.1^{-1}\right)$ & ++ & 42 & 26 & - & 27 & 21 & ns & 64 & 11 \\
\hline
\end{tabular}

The direct input of riverine organic matter that increases APA is probably less important since in Po River waters, the contribution of DOP to the total dissolved $\mathrm{P}$ pool is low (about 30\%) compared to $\mathrm{PO}_{4}$ (70\%; Milan et al. 2003).

\section{Seasonal changes of APA}

During spring and summer, when the water column was stratified, upper waters were poor in $\mathrm{PO}_{4}$ and DIN was present in surplus. In these conditions high APA developed. Fractionation showed that enzymatic activity was restricted to the particulate fraction, i.e. to microbes. A significant correlation of APA with microbial biomass and markedly lower DOP concentrations than during the period with

During the mixing period, APA had a significant positive correlation with chl a (Table 1). The other correlations were not significant. $\mathrm{Chl} a$ and BA were also significantly correlated. Multiple regression analysis indicated that $61 \%$ of APA variability could be explained by nutrients and microbial biomass. Chl a and BA could explain $42 \%$ and $11 \%$ of the variability, respectively, while little variability could be explained by the other parameters (Table 1).

\section{DISCUSSION}

\section{Spatial changes of APA}

The inverse correlation of APA with salinity in upper waters showed that the spreading of freshwater markedly influenced activity. In the upper waters of the eastern area, APA was within the range of values reported by Danovaro et al. (2005) for a more southern area of the northern Adriatic, while in the lower-salinity waters of the western and central areas, activity was markedly higher. It is known that Po River waters bring nutrients which stimulate microbial growth. After correlating photosynthetic efficiency with nutrients' concentrations, Zoppini et al. (1995) reported a surplus of $N$, with respect to $P$, in the coastal area affected by the Po River waters. The present study has shown that the freshwater surplus of $\mathrm{N}$ supply stimulated microbial growth, as indicated by the significant correlations of $\mathrm{BA}$ and chl a with DIN, until $\mathrm{PO}_{4}$ was exhausted. To meet microbial $\mathrm{P}$ requirements, APA was induced, and this could explain the significant influence of DIN on APA. low APA suggested that microbes obtained P by enzymatic hydrolysis of DOP. The individual contributions of bacterial abundance and chl a to changes in APA suggested that bacteria could be even more P-limited than phytoplankton.

Maximal APA was found during the freshets through the stratification period when microbial growth was stimulated by the Po River nutrient discharge. The unbalanced freshwater supply of nutrients caused a strong phosphorus deficit. The highest APA found in the Po River plume (5.55 $\left.\mu \mathrm{mol} \mathrm{l}^{-1} \mathrm{~h}^{-1}\right)$ was close to the maximal potential phosphorus concentrations in these waters (total phosphorus input by freshwater is $5.16 \mu_{\mathrm{mol}} \mathrm{l}^{-1}$ on average; see 'Introduction'). From these data, APA-mediated turnover time of $\mathrm{PO}_{4}$ could be estimated at about $1 \mathrm{~h}$. Even though turnover time is estimated from maximal potential APA and not from real APA, which is probably much lower, it does not appear to be an unrealistic value. Similarly, fast $\mathrm{PO}_{4}$ turnover (about $1 \mathrm{~h}$ ) and high APA were found in the Gironde plume during spring in P-limiting conditions, compared to much longer turnover times (about $10 \mathrm{~d}$ ) combined with low APA during winter, when $P$ was not limiting (Labry et al. 2002).

In summer months in which the Po River runoff was low, assimilation processes decreased the concentration of nutrients in upper 'old' lower-salinity waters. In these months APA was lower than during freshets through the stratification period. Specific APA, which gives a good insight into microbial P-limitation, although not all microbial cells nor groups respond equally to P-stress (e.g. Lomas et al. 2004), was high during the summer months, showing that microbes expressed enzymatic activity to obtain P. However, a low riverine supply of DIN limited microbial biomass, especially in June, and therefore there was no need for high 
APA as during the freshets. A similar pattern was also found in the Bay of Biscay, where the high N:P ratio of the riverine nutrient supply induced high APA during the spring freshets, while APA was lower during low riverine influence in summer (Labry et al. 2005).

From October to December low APA $(<0.2 \mu \mathrm{mol})^{-1}$ $\mathrm{h}^{-1}$ ) and DOP accumulation were observed in upper waters of the entire area. Although chl $a$ and BA could explain much APA variability, in this period very low specific APA was found. This shows that microbes were not P-limited and enzymatic hydrolysis of DOP was not appreciable, not even in October 2004 when phytoplankton biomass was the highest of that year. Since low specific APA during autumn and winter, with respect to spring and summer, did not correspond to changes in plankton community (Table A2 in supplementary material), the lack of P-limitation was not due to changes in microbial community between these periods, but probably to a more balanced nutrient supply. In these months vertical mixing enriched upper waters with nutrients from deeper waters where their ratio was usually close to equilibrated for microbial requirements, as also found by Degobbis (1990) (N:P was 12 to 21). A similar mechanism of nutrient supply from deeper waters and low APA were observed in October in the Bay of Biscay (Labry et al. 2002). A decrease of specific APA in relation to upward $\mathrm{PO}_{4}$ flux was also observed in the central Atlantic (Vidal et al. 2003).

In waters below $10 \mathrm{~m}$, APA was low (generally $<0.2 \mu \mathrm{mol} \mathrm{l}^{-1} \mathrm{~h}^{-1}$ ), and during the stratification period usually an order of magnitude lower than in the upper $10 \mathrm{~m}$. Temperatures in upper waters were from 1 to $11^{\circ} \mathrm{C}$ higher than in deeper waters and in this temperature range APA would only be expected to double (Petersson \& Jansson 1978). The significant negative correlation of APA with $\mathrm{PO}_{4}$ in deeper waters shows that APA was suppressed by $\mathrm{PO}_{4}$. A negative correlation between APA and chl $a$, as well as a negligible contribution of chl a to APA variability, showed that phytoplankton in these waters was not P-limited. Even if relatively high APA changes could be explained by BA, their negative correlation showed that bacteria in those waters were not P-limited. Elevated APA in deeper waters during May and June was possibly due to the sinking of cells and their successive degradation and enzyme release. Results obtained in 2006 showed that most of the activity in these waters was due to free enzymes.

\section{CONCLUSIONS}

The results reported herein show that APA plays an important role in P-recycling in the northern Adriatic. Its importance varied markedly during the year, and with depth. In upper waters activity was high and related to microbial biomass during spring and summer (e.g. stratification period) when the P supply depended on P-recycling in these waters or on freshwater input.

The start of mixing processes in the water column drastically decreased APA in upper waters. Consequently, APA, as well as specific APA, was very low during autumn and winter, even in conditions of high microbial biomass. The decrease in enzymatic activity was most likely due to a more balanced nutrient supply from bottom waters.

In bottom waters APA was not important for the supply of $\mathrm{P}$ for the microbial communities. In contrast to upper waters, here APA was mostly due to the activity of free enzymes.

Acknowledgements. The authors thank T. Đakovac, T. Šilović, I. Korenić, R. Rabak and the crew of RV 'Vila Velebita' for help during sampling and analyses. M. Devescovi is thanked for his advice on statistical analyses. Three anonymous referees are thanked for their constructive advice. This work is part of the scientific projects 'Structure and physiology of microbial communities in northern Adriatic fronts' (098-0982705-2729), 'Mechanism of long-term changes in the northern Adriatic ecosystem' (098-0982705-2731) and Project 'Jadran' funded by the Ministry of Science, Education and Sport of the Republic of Croatia.

\section{LITERATURE CITED}

Antia NJ, McAllister CD, Parsons TR, Stephens K, Strickland JDH (1963) Further measurements of primary production using a large-volume plastic sphere. Limnol Oceanogr 8: 166-183

> Artegiani A, Bregant D, Paschinik E, Pinardi N, Raicich F, Russo A (1997) The Adriatic Sea general circulation. Part I: Air-sea interactions and water mass structure. J Phys Oceanogr 27:1492-1514

Chiaudani G, Vighi M (1982) Multistep approach to identification of limiting nutrients in Northern Adriatic eutrophied coastal waters. Water Res 16:1161-1166

> Cozzi S, Lipizer M, Cantoni C, Catalano G (2002) Nutrient balance in the ecosystem of the north western Adriatic Sea. Chem Ecol 18:1-12

Danovaro R, Armeni M, Luna GM, Corinaldesi C and others (2005) Exo-enzymatic activities and dissolved organic pools in relation with mucilage development in the Northern Adriatic Sea. Sci Total Environ 353:189-203

> Degobbis D (1990) A stoichiometric model of nutrient cycling in the northern Adriatic Sea and its relation to regeneration processes. Mar Chem 29:235-293

Degobbis D, Precali R, Ivančić I, Smodlaka N, Fuks D, Kveder $S$ (2000) Long-term changes in the northern Adriatic ecosystem related to anthropogenic eutrophication. Int $\mathrm{J}$ Environ Pollut 13:495-533

Filipić B, Ivančić I, Degobbis D (1989) Dynamics of northern Adriatic phytoplankton in enrichment experiments. Period Biol 91:172

Franco P, Michelato A (1992) Northern Adriatic Sea: oceanography of the basin proper and of the western coastal zone. Sci Total Environ (suppl):35-62 
Giani M (ed) (2003) Rapporto finale (Adriatico) processi di formazione delle mucillagini nell'Adriatico e nel Tirreno (MAT). Istituto Centrale per la Ricerca Scientifica e Tecnologica Applicata al Mare (ICRAM), Rome

Gilmartin M, Revelante N (1983) The phytoplankton of the Adriatic Sea: standing crop and primary production. Thalassia Jugosl 19:173-178

Gilmartin M, Degobbis D, Revelante N, Smodlaka N (1990) The mechanism controlling plant nutrient concentrations in the northern Adriatic Sea. Int Rev Ges Hydrobiol 75:425-445

Goldman JC, Caron DA, Dennet MR (1987) Regulation of gross growth efficiency and ammonium regeneration in bacteria by substrate C:N ratio. Limnol Oceanogr 32: 1239-1252

Hoppe HG (1983) Significance of exoenzymatic activities in the ecology of brackish water: measurements by means of methylumbelliferyl-substrates. Mar Ecol Prog Ser 11: 299-308

Hoppe HG (2003) Phosphatase activity in the sea. Hydrobiologia 493:187-200

Ivančić I, Degobbis D (1984) An optimal manual procedure for ammonia analysis in natural waters by the indophenol blue method. Water Res 18:1143-1147

Ivančić I, Degobbis D (1987) Mechanisms of production and fate of organic phosphorus in the northern Adriatic Sea. Mar Biol 94:117-125

Karner M, Fuks D, Herndl G (1992) Bacterial activity along a trophic gradient. Microb Ecol 24:243-257

Labry C, Herbland A, Delmas D (2002) The role of phosphorus on planktonic production of the Gironde plume waters in the bay of Biscay. J Plankton Res 24:97-117

Labry C, Delmas D, Herbland A (2005) Phytoplankton and bacterial phosphatase activities in relation to phosphate and DOP availability within the Gironde plume waters (Bay of Biscay). J Exp Mar Biol Ecol 318:213-225

Lee S, Fuhrman JA (1987) Relationships between biovolume and biomass of naturally derived marine bacterioplankton. Appl Environ Microbiol 53:1298-1303

Lipizer M, Cozzi S, Falconi C, Catalano G (1999) Seasonal fluctuations of DIN/DIP and DON/DOP ratios as a consequence of biological activity. Ann Ist Super Sanita 35: 383-388

Lomas MW, Swain A, Shelton R, Ammerman JW (2004) Taxonomic variability of phosphorus stress in Sargasso Sea phytoplankton. Limnol Oceanogr 49:2303-2310

Editorial responsibility: Ronald Kiene,

Mobile, Alabama, USA
Lyons DM, Supić N, Smodlaka N (2007) Geostrophic circulation patterns in the northeastern Adriatic Sea and the effects of air-sea coupling: May-September 2003. J Geophys Res 112:C03S08

Menzel DW, Corwin N (1965) The measurement of total phosphorus in seawater based on the liberation of organically bound fractions by persulfate oxidation. Limnol Oceanogr 10:280-182

Milan C, Trentini P, Ascanelli M, Bignami S, Barbieri C, Libono L, Malfato MG (2003) Valutazione dei carichi dei nutrienti del Po a Pontelagoscuro. In: Giani M (ed) Rapporto finale (Adriatico) processi di formazione delle mucillagini nell'Adriatico e nel Tirreno (MAT). Istituto Centrale per la Ricerca Scientifica e Tecnologica Applicata al Mare (ICRAM), Rome, p 727-749

Petersson K, Jansson M (1978) Determination of phosphatase activity in lake water: a study of methods. Verh Int Verein Limnol 20:1226-1230

Pojed I, Kveder S (1977) Investigation of nutrient limitation of phytoplankton production in the northern Adriatic by enrichment experiments. Thalassia Jugosl 13:13-24

Porter KG, Feig YS (1980) The use of DAPI for identifying and counting aquatic microflora. Limnol Oceanogr 25: 943-948

Redfield AC, Ketchum BH, Richards FA (1963) The influence of organisms on the composition of seawater. In: Hill MN (ed) The sea, Vol 2. Interscience, New York, p 27-77

Sebastian M, Niell FX (2004) Alkaline phosphatase activity in marine oligotrophic environments: implications of singlesubstrate addition assays for potential activity estimations. Mar Ecol Prog Ser 277:285-290

Strickland JDH, Parsons TR (1972) A practical handbook of seawater analysis. Bull Fish Res Board Can 167:1-310

Utermöhl H (1958) Zur Vervollkommnung der quantitativen Phytoplankton-Methodik. Mitt Int Verein Theor Angew Limnol 17:47-71

- Vidal M, Duarte CM, Agusti S, Gasol JM, Vaque D (2003) Alkaline phosphatase activities in the central Atlantic Ocean indicate large areas with phosphorus deficiency. Mar Ecol Prog Ser 262:43-53

> Zoppini A, Pettine M, Totti C, Puddu A, Artegiani A, Pagnotta R (1995) Nutrients, standing crop and primary production in western coastal waters of the Adriatic Sea. Estuar Coast Shelf Sci 41:493-513

Submitted: April 17, 2008; Accepted: November 19, 2008 Proofs received from author(s): March 4, 2009 